\title{
CONNECTION OF THE INTENSITY OF THE FLUX OF SCR PROTONS WITH THE VELOCITY OF THE CME AND WITH THE FADING OF THE RADIO EMISSION OF THE SUN IN THE DECAMETER RANGE
}

\author{
E.A. Isaeva \\ Institute of Radio astronomy of NAS of Ukraine, <isaevaode@gmail.com>
}

\begin{abstract}
The relationship between SCR and CME and with fading of the continuum of noise storms and type IV radio bursts in the decameter range is investigated. It was shown earlier that about $60 \%$ of CMEs associated with solar proton events are accompanied by deep fading of the solar radio emission in the decameter range, which coincides in time with CME registration. It has also been shown that fading is characterized by fading depth, the frequency bandwidth in which the fading occurs, as well as the duration of the fading and the frequency at which the maximum fading depth is observed.

Further detailed studies have shown that for proton events accompanied by fading of the solar radio emission in the decameter range, the relationship between the intensity of the SCR proton flux and the CME velocity is much worse than for events without fading of the solar radio emission in the decameter range. However, it was found that for such events, the relationship between the flux of SCR protons and the CME velocity significantly increases if we take into account the fading depth of the solar radio emission in the decameter range.

Earlier in (Isaeva, 2019), the results of a study of the relationship between the intensity of fading of the continuum of noise storms with the parameters of X-ray bursts, with the $\mathrm{CME}$ velocity and the velocity of coronal shock waves, as well as with the intensity of the SCR proton flux were presented. This paper presents the results of studying the relationship between the intensity of the SCR proton flux with the parameters of type II and IV radio bursts, as well as with the CME velocity and with the velocity of coronal shock waves, depending on the intensity of fading of the solar radio emission in the decameter range at a frequency of $27 \mathrm{MHz}$. The frequency of $27 \mathrm{MHz}$ was chosen because in the region of this frequency the maximum fading depth of the solar radio emission in the decameter range is observed.
\end{abstract}

АНОТАЦІЯ. Досліджено зв'язок між СКП і КВМ, а також 3 завмираннями континууму шумових бур i радіо- сплесків IV типу в декаметровому діапазоні. Раніше було показано, що близько 60\% КВМ, пов'язаних 3 сонячними протонними подіями, супроводжуються глибокими завмираннями сонячного радіовипромінювання в декаметровому діапазоні, які збігаються за часом з реєстрацією КВМ. Також було пока- зано, що завмирання характеризуються глибиною завмирання, частотною смугою, в якій відбуваються завмирання, а також тривалістю замираний і частотою, на якій спостерігається максимальна глибина завмирання.

Подальші детальні дослідження показали, що для протонних подій, що супроводжуються загасанням сонячного радіовипромінювання в декаметровому діапазоні, зв'язок між інтенсивністю потоку протонів СКП і швидкістю КВМ набагато гірше, ніж для подій без загасання сонячного радіовипромінювання в декаметровому діапазоні. Однак виявилося, що для таких подій зв'язок між потоком протонів СКП і швидкістю КВМ істотно зростає, якщо врахувати глибину завмирання радіовипромінювання Сонця в декаметровому діапазоні.

Раніше в роботі (Isaeva, 2019) були представлені результати дослідження зв'язку інтенсивності завмираний континууму шумових бур з параметрами рентгенівських сплесків, зі швидкістю КВМ і швидкістю корональних ударних хвиль, а так само з інтенсивністю потоку протонів СКП. У даній роботі представлені результати дослідження зв'язку інтенсивності потоку протонів СКП з параметрами радіосплесків II і IV типу, а також зі швидкістю КВМ і зі швидкістю корональних ударних хвиль в залежності від інтенсивності завмираний радіовипромінювання Сонця в декаметровому діапазоні на частоті 27 МГц. Частота 27 МГц обрана тому, що в районі даної частоти спостерігається максимальна глибина завмирань радіовипромінювання Сонця в декаметровому діапазоні.

Keywords: CME velocity, fading of the continuum of noise storms, intensity of the SCR proton flux.

\section{Introduction}

The interest in coronal mass ejections is due to their high geoeffectiveness.

Broadband studies in the radio range have shown that most CME formation events are accompanied by sporadic events in the radio range (about $80 \%$ of the total number of cases). In $50 \%$ of cases, phenomena in the radio range, previous CME registrations are broadband. At the same time, it was shown that CMEs, which are not accompanied by broadband phenomena in the radio range, are ejections 
with a small angular width $<40^{\circ}$ and an average ejection velocity of no more than $700 \mathrm{~km} / \mathrm{s}$.

The generalization of observational data in the radio range indicates that at the stage of CME formation in the meter-decameter ranges, an increase in the continuum of noise storms with characteristic quasiperiodic oscillations is observed up to the complete fading of noise storms before the CME emerges (Durasova et al., 1999; 2002). In the centimeter-decimeter ranges at the stage of CME formation, an increase in the intensity of microwave radiation is observed, as well as powerful bursts of the GRF type with characteristic time fluctuations in the flux intensity with periods $>20$ minutes, and immediately before the CME exit, within 10-15 minutes, there are short-period fluctuations in flux intensity with periods ranging from 622 seconds (Grechnev, 2003; Fridman \& Sheiner, 2008).

It should also be noted that there is a strong connection between CMEs and broadband type IV continuum radio bursts. It is shown in (Isaeva \& Tsap, 2017) that there is a strong relationship between the CME velocity and the integral flux of microwave bursts ( $\mu$ - bursts) for proton events. Moreover, the relationship between the CME velocity and the integral flux of type IV continuum bursts largely depends on the frequency of the continual radio burst. With a decrease in the frequency of radio emission of continual bursts, the relationship between the $\mathrm{CME}$ velocity and the integral flux of continuous bursts sharply decreases and already in the meter-decameter wavelength ranges is practically absent.

\section{Initial data and research results}

The sample under study contains 112 solar proton events (SPEs) for the period from 24-11-2000 to 23-07-2016 years, accompanied by coronal mass ejections (CMEs). Out of $112 \mathrm{CME}$ events, $67(\approx 60 \%)$ were accompanied by the fading of the continuum of noise storms and type IV continuum bursts in the decameter range at frequencies of 25 $30 \mathrm{MHz}$.

For the analysis, we used the original recordings of dynamic spectra in the $25-180 \mathrm{MHz}$ range from the Solar Radio Spectrograph (SRS) (http://www.ngdc.noaa. gov/stp/space-weather/solar-data/solar-features/solar-radio

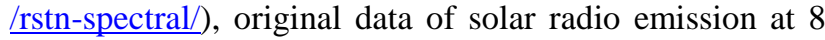
fixed frequencies 245, 410, 610, 1415, 2695, 4995, 8800 and $15400 \mathrm{MHz}$ according to data from the RSTN radio telescope (https://www.ngdc.noaa.gov/stp/spaceweather/solar-data/solar-features/solar-radio/rstn-1second/), data on coronal mass ejections (CMEs) (https://cdaw.gsfc.nasa.gov/CME_list/UNIVERSAL/text_ ver/univ_all.txt), list of proton events (ftp://ftp.swpc. noaa gov/pub/indices/SPE.txt), original records of X-ray radiation from the Sun in the range of 1-8 $\AA$ and proton flux intensity $I_{p}$ with energy $E_{p}>1-100 \mathrm{MeV}$ according to data from GOES (https://satdat.ngdc.noaa. gov/sem/goes /data/new avg/).

A comparative analysis showed that the fading of noise storms is characterized by the frequency bandwidth $\Delta f$, the maximum intensity (depth) $F_{\max }$, the duration $d$ and the frequency $f_{\max }$ at which the maximum fading depth is observed. For most events, the fading of noise storms is observed in a narrow frequency band $\Delta f$ from $125 \mathrm{kHz}$ to 2 $\mathrm{MHz}$. However, for some events, fading can be observed in

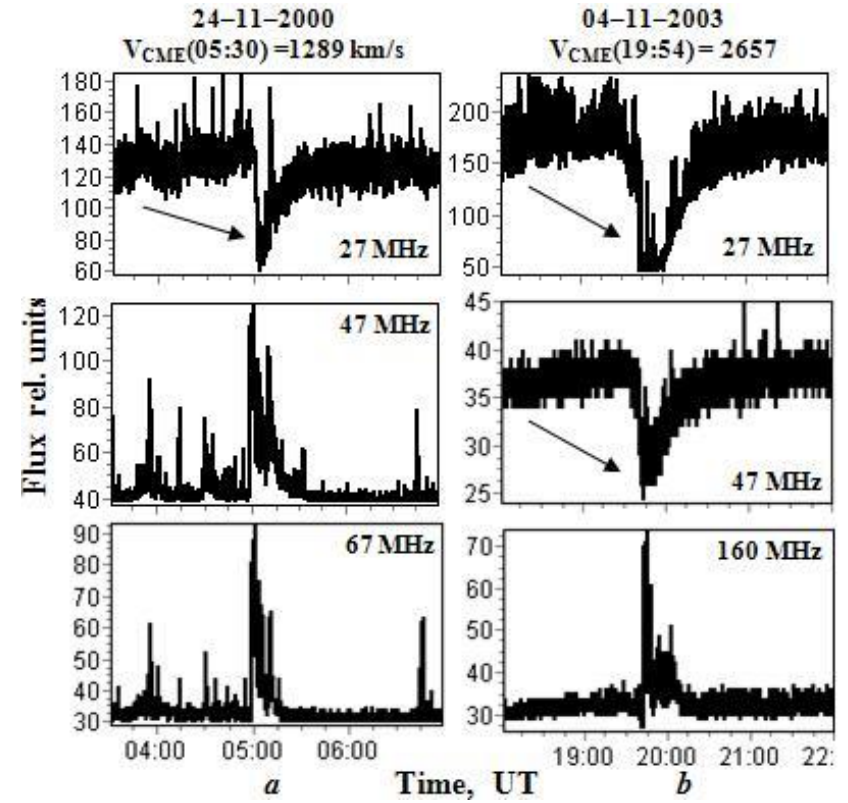

Figure 1: An example of fading of the continuum of noise storms and continuum bursts associated with CME.

the 40-60 MHz band, for example, as for the 04-11-2003 event, see fig. 1 . In fig. 1 shows examples of the attenuation of the continuum of noise storms and type IV continuum bursts at fixed frequencies, taken from the original records of dynamic spectra with the Solar Radio Spectro-graph. The fading effect of noise storms is shown with black arrows. Above the figures, the date, registration time and speed of the CME are indicated.

For most events, the maximum intensity (depth) of fading $F_{\max }$ is observed in the frequency region $f_{\max } \approx 27 \mathrm{MHz}$.

The purpose of this work was to investigate the relationship between the intensity of the SCR proton flux with the CME velocity, with the velocity of coronal shock waves, as well as with different parameters of type II and IV radio bursts on the fading intensity. Comparative analysis showed that fading has the strongest effect on the relationship between the SCR proton flux and the CME velocity, as well as with the parameters of type II radio bursts. At the same time, the influence of fading on the relationship between the flux of SCR protons and the parameters of microwave bursts turned out to be insignificant.

\section{Relationship between the intensity of the SCR} proton flux $I_{p}$ and the CME velocity $V_{C M E}$ taking into account the fading depth

In fig. 2 shows the relationship between the proton flux intensity and CME velocity without taking into account fading (fig. 2 a)) and taking into account fading (fig. 2 b)), where $N$ is the number of events, $r$ is the correlation coefficient between the parameters under study, $k=F_{z} / F_{\text {sun }}$ - coefficient characterizing the intensity of fading, which is equal to the ratio of the intensity of the fading depth $F_{z}$ to the intensity of the solar flux before fading $F_{\text {sun }}$, see fig. 3 . In fig. 2 b) it can be seen that if we take into account coefficient $k$, then the variance between $I_{p}$ and the product $V_{C M E}$ - $k$ decreases significantly, and the correlation coefficient $r$ increases from 0.66 to 0.82 . 


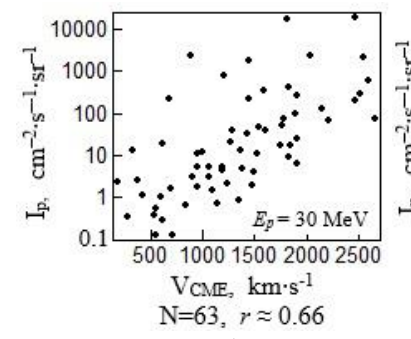

a).

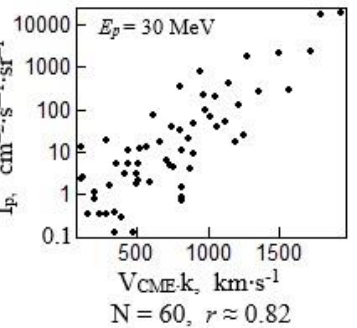

b).
Figure 2: Relationship of the intensity of the proton flu SCR $I_{p}$ with CME velocity $V_{C M E}$ without fading (a) taking into account fading (b).

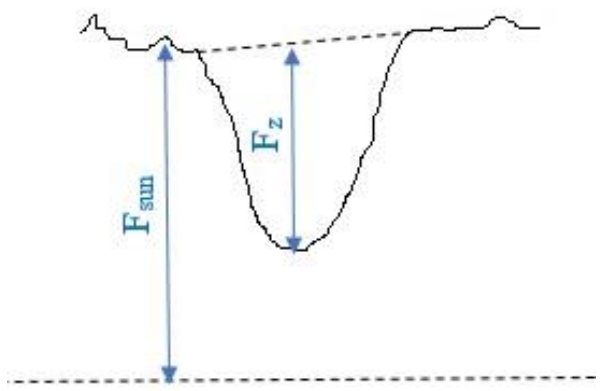

Figure 3: Scheme for processing noise storm continuum fading.

\section{Relationship between the intensity of the pro- ton flux $I_{p}$ and the parameters of type II radio bursts, taking into account the depth of fading}

Detailed studies have shown that the relationship between the intensity of the SCR proton flux $I_{p}$ with the parameters of type II radio bursts increases significantly if the fading depth is taken into account. To study the relationship between the proton flux $I_{p}$ and the parameters of type II radio bursts, three parameters were chosen: the coefficient $a_{j}$ in the linear regression model (1) to approximate the harmonics of type II bursts, the minimum relative distance between the harmonics of a type II burst $b_{\min }(2)$ and the value of the frequency $f_{\min , 1}$ at the fundamental harmonic (at the first) at the time $t_{\min }$ of the minimum relative distance between the harmonics.

$$
\begin{aligned}
& \log _{10} f_{i, j}=a_{j} \cdot \sqrt{t_{i}}+d_{j} \\
& b_{\text {min }}=\frac{\left(f_{i, 2}-f_{i, 1}\right)}{f_{i, 1}}
\end{aligned}
$$

In formula (1) $f_{i, j}$ is the frequency value at a given time moment $t_{i}, i$ is the number of the sample, $j$ is the number of the harmonic, $a_{j}$ and $d_{j}$ are the linear regression coefficients. In formula (2) $f_{i, 1}$ and $f_{i, 2}$ are the frequency values at the first and second harmonics at a given time $t_{i}$.

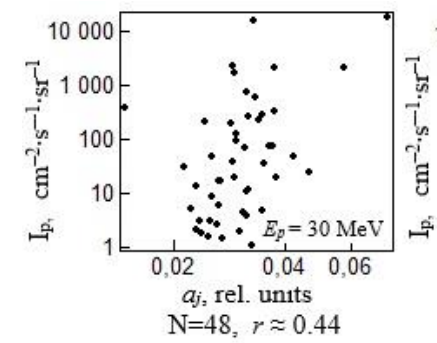

a)

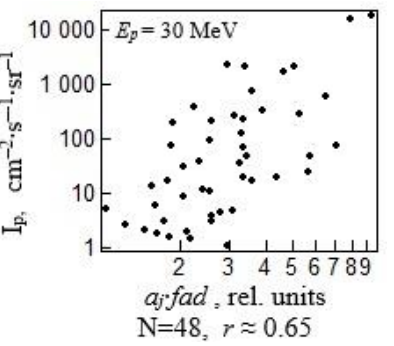

b).
Figure 4: Relationship of the proton flux intensity $I_{p}$ with $a_{j}$ without taking into account fading (a) and taking into account fading (b).

Figure 4 shows the relationship between the proton flux $I_{p}$ and the coefficient $a_{j}$ in model (1), which characterizes the decrease in the frequency drift velocity over time $t_{i}$. In fig. 4 a) shows the relationship between $I_{p}$ and $a_{j}$ without taking into account the fading depth, and fig $4 \mathrm{~b}$ ) taking into account the fading depth. Comparative analysis showed that the strongest relationship between $I_{p}$ and $a_{j}$ is observed if the fading depth $\mathrm{fad}=F_{z}$ is taken into account, and not the coefficient $k=F_{z} / F_{\text {sun }}$. In fig. 4 that if the fading depth is taken into account, then the correlation coefficient $r$ between $I_{p}$ and $a_{j}$ increases from 0.44 to 0.65 .

Earlier in (Isaeva, 2019; Tsap, Isaeva, Kopylova, 2020), it was shown that the relative distance between the harmonics of type II bursts decreases monotonically over time to a minimum value, and then monotonically increases. Moreover, in (Isaeva, 2019; 2020) it was shown that there is a fairly strong relationship between the intensity of the proton flux $I_{p}$ with the frequency $f_{\min , 1}$ at the moment of the minimum relative distance $b_{\text {min }}$, while the relationship between $I_{p}$ and $b_{\min }$ turned out to be significantly weaker than with $f_{\min , 1}$. It was shown that the correlation coefficient $r$ between $I_{p}$ and $b_{\min }$ does not exceed 0.63 , while the correlation coefficient $r$ between $I_{p}$ and the frequency $f_{\min , 1}$ was $\approx 0.70-0.79$ for different samples of proton events.

It was already noted above that for events accompanied by fading of the solar radio emission in the decameter range, there is a poor correlation between the proton flux and the parameters of type II radio bursts.

In this regard, the relationship between the proton flux intensity $I_{p}$ with the minimum relative distance $b_{\min }$ and with the frequency $f_{\min , 1}$ at the first harmonic was investigated, taking into account the fading depth. A comparative analysis has shown, if the fading depth is taken into account, then the relationship between the proton flux $I_{p}$ with $b_{\min }$ and with the frequency $f_{\min , 1}$ sharply increases (see fig. 5 and 6). However, the effect of fading on the relationship between $I_{p}$ and $b_{\min }$ and frequency $f_{\min , 1}$ is different. In the first case, the maximum correlation is observed if we consider the relationship between $I_{p}$ and the multiplication $b_{\text {min }}$ - $\mathrm{fad}$, and in the second case, if we consider the relationship between $I_{p}$ and the ratio $f_{m i n, 1} / f a d$. 


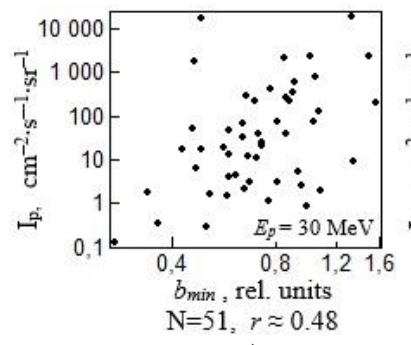

a).

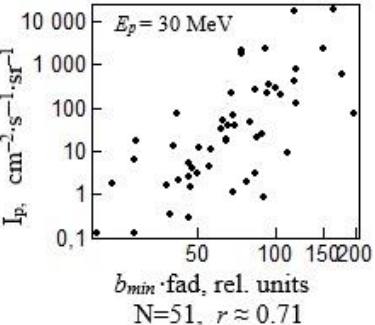

b).
Figure 5: Relationship of the proton flux intensity $I_{p}$ with $b_{\min }$ without taking into account fading (a) and taking into account fading (b).

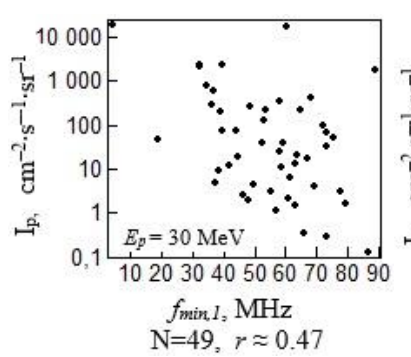

a).

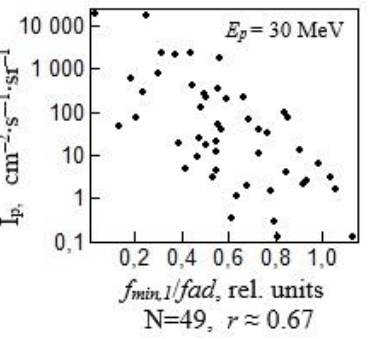

b).
Figure 6: Relationship of the proton flux intensity $I_{p}$ with $f_{\text {min, }, I}$ without taking into account fading (a) and taking into account fading (b).

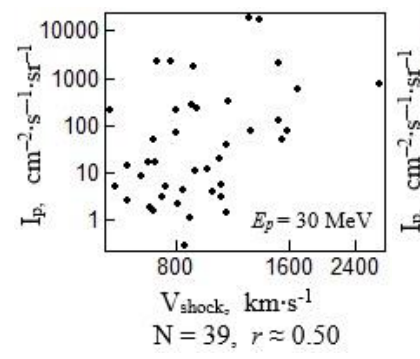

a).

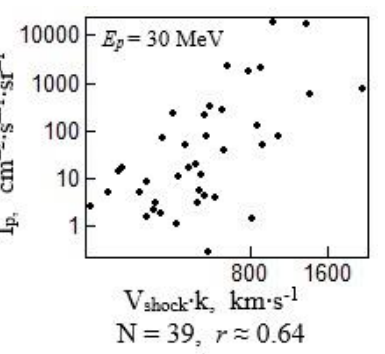

b).
Figure 7: Relationship between the intensity of the SCR proton flux $I_{p}$ with the velocity of shock waves $V_{\text {shock }}$ without taking into account fading (a) and taking into account fading (b).

\section{Relationship between the intensity of the SCR} proton flux $I_{p}$ and the shock wave velocity $V_{\text {shock }}$

For the analysis, we used tabular data on the velocity of shock waves $V_{\text {shock }}$ (https://www.ngdc.noaa.gov/stp/spaceweather/solar-data/solar-features/solar-radio /radio-bursts /reports /spectral-listings/ Type II /Type II_1994-2009). Due to the fact that the estimated tabular values of the shock wave velocity are not available for all proton events, therefore, the sample under study contains only 39 proton events. Detailed studies have shown that the relationship between the proton flux $I_{p}$ and the velocity of shock waves $V_{\text {shock }}$ is low (see fig. 7 a)) and the correlation coefficient $r$ between the parameters under study does not exceed 0.50 .

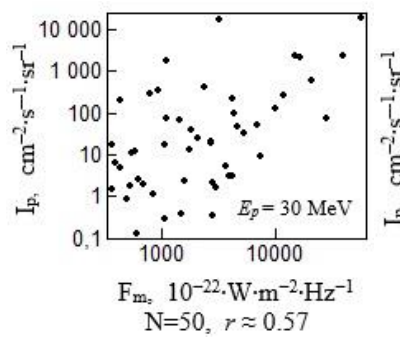

a).

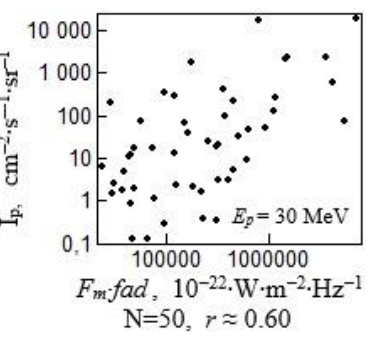

b).
Figure 8: Relationship of the proton flux intensity $I_{p}$ with the maximum value of $\mu$-bursts $F_{m}$ without taking into account fading (a) and taking into account fading (b).

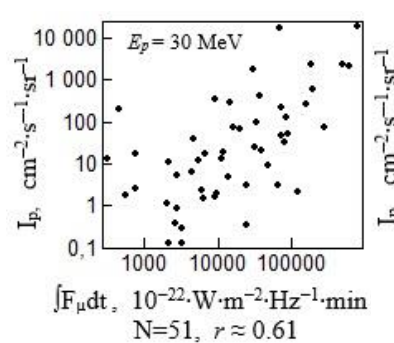

a).

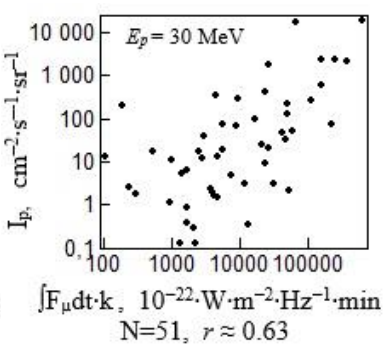

b).
Figure 9: Relationship of the proton flux intensity $I_{p}$ with the time-integrated flux density of $\mu$-bursts $\int F_{\mu} d t$ without taking into account fading (a) and taking into account fading (b).
However, if we consider the relationship between $I_{p}$ and the velocity of shock waves $V_{\text {shock}}$, taking into account the intensity of fading, then the link between $I_{p}$ and the velocity of shock waves $V_{\text {shock }}$ increases significantly (see fig. 7 b)).

6. Relationship between the intensity of the SCR proton flux $I_{p}$ and the parameters of microwave bursts, taking into account the depth of fading.

The sample under study contained 51 proton events accompanied by type IV microwave radio bursts ( $\mu$-bursts) at a frequency of $8800 \mathrm{MHz}$, as well as fading of the continuum of noise storms in the decameter range at a frequency of $27 \mathrm{MHz}$.

Relationship the intensity of the proton flux $I_{p}$ with the maximum value of $F_{m}$ and with time-integrated flux density $\int F_{\mu} d t$ during the duration of $\mu$-bursts at a frequency of $8800 \mathrm{MHz}$ was investigated.

Comparative analysis showed that fading of the solar radio flux in the decameter range practically does not affect the relationship between the intensity of the proton flux $I_{p}$ and the parameters of $\mu$-bursts $F_{m}$ and $\int F_{\mu} d t$ (see fig. 8 and 9). As seen in fig. 8 and fig. 9, the correlation coefficient $r$ between the intensity of the proton flux $I_{p}$ and the parameters of microwave bursts at a frequency of $8800 \mathrm{MHz}$, after taking into account the fading intensity of the continuum of noise storms, increased by only $2-3 \%$. 


\section{Conclusions}

Detailed studies have shown that the strongest effect of fading of solar radio emission in the decameter range is on the relationship between the intensity of the proton flux $I_{p}$ and the CME velocity $V_{C M E}$, as well as on the relationship between the proton flux $I_{p}$ and the parameters of type II radio bursts. At the same time, the effect of fading on the relationship between the proton flux intensity $I_{p}$ and the parameters of microwave bursts turned out to be insignificant.

\section{References}

Durasova M. Fridman V., Sheiner O.: 1999, Proc. $9^{\text {th }}$ European Miting on Solar Phisics. (ESA,SP-448, December 1999). 972.

Durasova M., Fridman V., Sheiner O.: 2002, Proc. SOLSPA, (ESA SP-477, February 2002), 373.
Fridman V., Sheiner O.: 2008, Солнечно-земная физика, № $12, \mathbf{1}, 79$.

Grechnev V.: 2003, Astrophys. J., 588, 1163.

Isaeva E., Tsap Yu.: 2017, Odessa Astron. Publ., 30, 222.

Isaeva E.: 2019, Odessa Astron. Publ., 32, 97.

Isaeva E.: 2019, Odessa Astron. Publ., 32, 122.

Tsap Yu., Isaeva E., Kopylova Yu.: 2020, Astron. Lett., 46, № 2, 144 .

Sheiner O., Fridman V.: 2005, Cambrige University Press, 233.

Sheiner O., Fridman V.: 2005, Cambrige University Press, 235. 